OPEN ACCESS

Edited by: Juan Aguirre,

Universidad de Chile, Chile

Reviewed by:

Evandro De Souza,

Federal University of Paraíba, Brazi Vittorio Capozzi, University of Foggia, Italy

*Correspondence: Andrea Gómez-Zavaglia angoza@qui.uc.pt

Specialty section: This article was submitted to

Food Microbiology, a section of the journal

Frontiers in Microbiology

Received: 24 September 2016 Accepted: 29 March 2017 Published: 12 April 2017

Citation:

Quintana G, Gerbino E and Gómez-Zavaglia A (2017) Okara: A Nutritionally Valuable By-product

Able to Stabilize Lactobacillus plantarum during Freeze-drying,

Spray-drying, and Storage.

Front. Microbiol. 8:641.

doi: 10.3389/fmicb.2017.00641

\section{Okara: A Nutritionally Valuable By-product Able to Stabilize Lactobacillus plantarum during Freeze-drying, Spray-drying, and Storage}

\author{
Gabriel Quintana, Esteban Gerbino and Andrea Gómez-Zavaglia* \\ Center for Research and Development in Food Cryotechnology (CCT-CONICET La Plata), Buenos Aires, Argentina
}

Okara is a nutritionally valuable by-product produced in large quantities as result of soymilk elaboration. This work proposes its use as both culture and dehydration medium during freeze-drying, spray-drying, and storage of Lactobacillus plantarum CIDCA 83114. Whole and defatted okara were employed as culture media for $L$. plantarum CIDCA 83114. The growth kinetics were followed by plate counting and compared with those of bacteria grown in MRS broth (control). No significant differences in plate counting were observed in the three media. The fatty acid composition of bacteria grown in whole and defatted okara showed a noticeable increase in the unsaturated/saturated $(U / S)$ fatty acid ratio, with regard to bacteria grown in MRS. This change was mainly due to the increase in polyunsaturated fatty acids, namely C18:2. For dehydration assays, cultures in the stationary phase were neutralized and freeze-dried (with or without the addition of $250 \mathrm{mM}$ sucrose) or spray-dried. Bacteria were plate counted immediately after freeze-drying or spray-drying and during storage at $4^{\circ} \mathrm{C}$ for 90 days. Freeze-drying in whole okara conducted to the highest bacterial recovery. Regarding storage, spraydried bacteria previously grown in whole and defatted okara showed higher plate counts than those grown in MRS. On the contrary, freeze-dried bacteria previously grown in all the three culture media were those with the lowest plate counts. The addition of sucrose to the dehydration media improved their recovery. The higher recovery of microorganisms grown in okara after freeze-drying and spray-drying processes and during storage was ascribed to both the presence of fiber and proteins in the dehydration media, and the increase in U/S fatty acids ratio in bacterial membranes. The obtained results support for the first time the use of okara as an innovative matrix to deliver L. plantarum. Considering that okara is an agro-waste obtained in large quantities, these results represent an innovative strategy to add it value, providing a symbiotic ingredient with promising industrial applications in the development of novel functional foods and feeds.

Keywords: okara, Lactobacillus plantarum, fatty acid composition, preservation process, storage 


\section{INTRODUCTION}

Okara is a white-yellowish puree remaining after filtration of the smashed soybeans seeds used for the production of soymilk (Stanojevic et al., 2013), and is produced in large quantities (about $1.1 \mathrm{~kg}$ per kilogram of soybean processed for soymilk production) (Li Y. et al., 2012). It is rich in high quality proteins, unsaturated lipids and dietary fiber, and also contains isoflavones, minerals and oligosaccharides (i.e., raffinose, stachyose) (Jimenez-Escrig et al., 2008; Song et al., 2009). Because of this nutritional richness, and the high water activity, okara is very prone to putrefaction. Although this agro-waste is generally used for animal feed, surplus is still burned as waste or dumped as landfill (Vong and Liu, 2016), which entails a significant disposal problem. For this reason, it is important to find novel strategies to add value to this material.

Several health benefits have been ascribed to okara, including antioxidant capacity, prevention of obesity and liver fat accumulation, decrease of cholesterol plasma levels and prevention of cardiovascular diseases (Jimenez-Escrig et al., 2008; Bedani et al., 2015; Vong and Liu, 2016). These properties make it a source of functional ingredients at a low cost (O’Toole, 1999; Li Y. et al., 2012). Okara was used as fermentation substrate to produce a variety of products for human consumption, including $\alpha$-glucosidase inhibitor, $\beta$-fructofuranosidase, fibrinolytic enzymes, iturin A, edible fungi, chitosan, alcohol, biosurfactants, among others (Kitawaki et al., 2007; Li B. et al., 2012; Li Y. et al., 2012; Villanueva-Suárez et al., 2013; Zhu et al., 2014; Vong and Liu, 2016). It was also used to supplement culture media or probiotic-containing products (Bedani et al., 2013, 2014). Inoculation of okara with lactic acid bacteria has been reported as an efficient approach to inhibit the growth of spoilage microorganisms (O'Toole, 1999) and to add value to this by-product (Lê et al., 2004; Espinosa-Martos and Rupérez, 2009; Villanueva-Suárez et al., 2013; Vong and Liu, 2016). Considering this, okara could be used as a cost-effective culture medium for the production of large quantities of starters at an industrial level.

Among lactic acid bacteria, Lactobacillus plantarum is a flexible and versatile species that is encountered in a variety of environmental niches, including some dairy, meat, and many vegetable or plant fermentations (Kleerebezem et al., 2003). Several strains of L. plantarum have demonstrated probiotic and technological properties. For this reason, the strains of this species have been used for a large number of applications, namely the formulation of fortified bread and pasta (Capozzi et al., 2011), as malolactic fermentation starter cultures (Berbegal et al., 2016), for the fermentation of regional beverages (Yadav et al., 2016), as antibiotic replacement (AlMadboly and Abdullah, 2015), and for the elimination of the

Abbreviations: $a_{w}$, water activity; CFUs, cell forming units; cyc19, 0 cyclopropane fatty acid (methyleneoctadecanoic acid); d.b., dry basis; EDTA, ethylenediaminetetraacetic acid; FAMEs, fatty acids methyl esters; FTIR, Fourier transform infrared spectroscopy; MUFAs, monounsaturated fatty acids; PBS, phosphate saline buffer; PUFAs, polyunsaturated fatty acids; U/S, unsaturated/saturated. undesirable biogenic amines in wines (Capozzi et al., 2012), among others. In particular, L. plantarum CIDCA 83114, a strain isolated from kefir grains, have demonstrated both probiotic and technological properties, including the inhibition of growth and/or activity of Escherichia coli O157:H7 and Salmonella (Golowczyc et al., 2011b; Kakisu et al., 2013), and the overcoming of thermal and dehydrating processes (Romano et al., 2014; Tavera-Quiroz et al., 2015). These properties make it a good candidate to grow in okara and add value to this by-product.

The production of lactic acid bacteria as industrial starters requires adequate stabilization processes to avoid bacterial damage or death. In general, starters are delivered to food companies, or directly to consumers, under the form of ready to use and highly concentrated products. The commercialization of these concentrated cultures requires the application of preservation (or stabilization) processes to increase their shelflife. Among them, freeze-drying has been the most widely used process (Fonseca et al., 2015). Spray-drying is an alternative technique that conducts to the transformation of liquid systems into dry particulate powders when they come into direct contact with a drying medium (air) at high temperatures. It has been increasingly used to dehydrate lactic acid bacteria (Golowczyc et al., 2010, 2011a,b, 2013; Sosa et al., 2016). It is a cost-effective process, especially suitable for the production of large quantities of microorganisms (Golowczyc et al., 2010, 2011a,b, 2013; Sosa et al., 2016).

During the preservation processes, the decrease of water activity produces damages on the bacterial structures, decreasing their viability (Tymczyszyn et al., 2007a). To prevent these damages, sugars are generally used as protective agents (Carvalho et al., 2004), sucrose and trehalose being the most widely used among lactic acid bacteria. More recently more complex sugars, namely fructo and galacto-oligosaccharides, inuline, fiber, have been successfully used (Santos et al., 2014; Romano et al., 2015). Considering that okara includes about $50 \%$ of oligo and polysaccharides (Vong and Liu, 2016), its use as dehydration medium during preservation processes could provide protective compounds, avoiding the addition of external protectants.

Taking this background into account, the aim of this work was twofold: to use okara as culture medium for L. plantarum CIDCA 83114; and to evaluate the stabilizing capacity of okara during bacterial freeze-drying, spray-drying and storage at $4^{\circ} \mathrm{C}$ for 90 days.

\section{MATERIALS AND METHODS}

\section{Raw Material, Centesimal Composition, and Fourier Transform Infrared assays (FTIR)}

Okara was obtained from Soyana S. H. (San Martín, Argentina). After being received, it was centrifuged five times to remove the excess of water. The sediment was frozen at $-80^{\circ} \mathrm{C}$ for $48 \mathrm{~h}$ and then, freeze-dried on a Heto FD4 equipment (Heto Lab Equipment, Denmark) for $48 \mathrm{~h}$ (temperature of condenser: $-50^{\circ} \mathrm{C}$; chamber pressure: $0.04 \mathrm{mbar}$ ). 
Moisture content of the freeze-dried okara was determined by measuring the weight loss upon drying in a vacuum oven at $70^{\circ} \mathrm{C}$ until constant weight (Association of Official Analytical Chemists [AOAC], 1980). Total nitrogen was determined using the Kjeldahl method (Association of Official Analytical Chemists [AOAC], 1995) (conversion factor to transform nitrogen into protein: 6.25). Lipids were assessed by extraction with diethyl ether solvent in a Soxhlet system (Association of Official Analytical Chemists [AOAC], 1995). Ash content was determined by carbonization of the dried samples followed by incineration in a muffle furnace at $550^{\circ} \mathrm{C}$. Dietary fiber was assessed using Megazyme testkit K-ACHDF 11/08 (Megazyme International Ireland Limited, Bray, Ireland) according to the manufacturer's procedure (McCleary, 2007). The centesimal composition was expressed in grams per $100 \mathrm{~g}$ of dry basis. The centesimal composition of defatted okara was determined after lipids' extraction (Association of Official Analytical Chemists [AOAC], 1995).

Fourier transform infrared spectroscopy spectra of freezedried whole and defatted okara were registered in the $4000-500 \mathrm{~cm}^{-1}$ range on $\mathrm{KBr}$ pellets, prepared in a 1:200 okara- $\mathrm{KBr}$ ratio. They were recorded in a transmission mode by co-adding 64 scans with $4 \mathrm{~cm}^{-1}$ spectral resolution, on a Thermo Nicolet iS10 spectrometer (Thermo Scientific, Waltham, MA, USA).

Whole and defatted okara were suspended in distilled water to obtain $5 \% \mathrm{w} / \mathrm{v}$ suspensions. The suspensions were homogenized in an Ultra Turrax T25 (IKA, Staufen im Breisgau, Germany) and autoclaved for $15 \mathrm{~min}$ at $121^{\circ} \mathrm{C}$. They were then used as culture media.

\section{Bacterial Strain, Culture Conditions, and Growth Kinetics}

Lactobacillus plantarum CIDCA 83114 was isolated from kefir grains (Garrote et al., 2001) maintained frozen at $-80^{\circ} \mathrm{C}$ in $120 \mathrm{~g} / \mathrm{L}$ non-fat milk solids (Difco, USA). Microbial cells were activated for $24 \mathrm{~h}$ in MRS broth (de Man et al., 1960) at $37^{\circ} \mathrm{C}$ in aerobic conditions. The resulting culture was inoculated ( $1 \%$ $\mathrm{v} / \mathrm{v})$ in fresh MRS broth and incubated in the same conditions. Cultures in the stationary phase [ $18 \mathrm{~h}$ incubation and $\sim 1 \times 10^{13}$ colony forming units per $\mathrm{mL}(\mathrm{CFU} / \mathrm{mL})]$ were used to inoculate $100 \mathrm{~mL}$ whole and defatted okara (inoculum concentration $2 \%$ $\mathrm{v} / \mathrm{v})$. They were then incubated at $37^{\circ} \mathrm{C}$ with shaking. In a parallel assay, microorganisms were grown in MRS broth in the same conditions (control). The three growth kinetics were followed by plate counting in MRS agar every $1 \mathrm{~h}$, and results were expressed in $\mathrm{CFU} / \mathrm{mL}$.

\section{Extraction of Lipids from Bacteria}

Microorganisms were grown in okara and defatted okara at $37^{\circ} \mathrm{C}$. Once attained the stationary phase, cultures were treated with $2 \% \mathrm{w} / \mathrm{v}$ EDTA $\mathrm{pH} 12$ for $10 \mathrm{~min}$ to sequester calcium from okara and partly solubilize insoluble structures (Holt, 1982). After the treatment with EDTA, cultures were centrifuged, supernatants were discarded and bacterial pellets were used for lipids' extraction. Controls: bacteria in the stationary phase grown in MRS, harvested by centrifugation, and washed with PBS [( $\left.\mathrm{K}_{2} \mathrm{HPO}_{4} 0.144 \mathrm{~g} / \mathrm{L} ; \mathrm{NaCl} 9.00 \mathrm{~g} / \mathrm{L} ; \mathrm{Na}_{2} \mathrm{HPO}_{4} \mathrm{~g} / \mathrm{L}\right), \mathrm{pH}$ 7].

Lipids were extracted according to the modified Bligh and Dyer method (Marinetti, 1993). Briefly, bacterial pellets from microorganisms grown in whole and defatted okara and in MRS were suspended in chloroform-methanol-water $(1: 2: 0.8 \mathrm{v} / \mathrm{v} / \mathrm{v})$ ( $4.75 \mathrm{~mL}$ per $\mathrm{g}$ of cells) for $12 \mathrm{~h}$ at $4^{\circ} \mathrm{C}$, and then centrifuged at $8000 \mathrm{~g}$ for $10 \mathrm{~min}$ at $10^{\circ} \mathrm{C}$. The supernatants were collected, and a second extraction on bacterial pellets was carried out. Both supernatants were mixed and chloroform-water (1:1) was added (12.5 $\mathrm{mL}$ per $\mathrm{g}$ of bacteria). The final mixture was centrifuged at $8000 \mathrm{~g}$ for $20 \mathrm{~min}$. The chloroform phase was collected and dried under vacuum (Rotavapor ${ }^{\circledR}$ RE 120 - Büchi, Flawil, Switzerland). Lipids were dissolved in chloroform (final concentration $3 \mathrm{mg} / \mathrm{mL}$ ) and stored at $-20^{\circ} \mathrm{C}$ for up to 2 weeks.

\section{Characterization of Fatty Acids}

The FAME were prepared by adding $2 \mathrm{~mL}$ sulfuric acid (20 g/L in methanol) to $3 \mathrm{mg}$ bacterial lipids, heating at $60^{\circ} \mathrm{C}$ for $2 \mathrm{~h}$, extracting the esters with $1 \mathrm{~mL}$ chloroform-water $(2: 0.7 \mathrm{v} / \mathrm{v})$ and washing twice with $0.7 \mathrm{~mL}$ water. The obtained FAME were analyzed on a gas chromatograph interfaced with a mass spectrometer detector (Shimadzu QP 5050A, Tokyo, Japan) using capillary column ZB-5 (30 m $\times 0.25 \mathrm{~mm})$. The analysis conditions were: injection temperature $250^{\circ} \mathrm{C}$, detector temperature $280^{\circ} \mathrm{C}$, and column temperature initially $100^{\circ} \mathrm{C}$ increased to $280^{\circ} \mathrm{C}$ at $6^{\circ} \mathrm{C} \mathrm{min}^{-1}$. The FAME were identified by mass spectrometry (GC-MS). The fatty acid composition was determined by considering the relative contribution of each peak area with regard to the sum of the areas corresponding to all peaks. Results were expressed as \% of the total area.

\section{Freeze-drying}

Microorganisms were grown in okara and defatted okara at $37^{\circ} \mathrm{C}$. Aliquots of $1 \mathrm{~mL}$ containing L. plantarum CIDCA 83114 were collected in the stationary phase and neutralized with $\mathrm{NaOH}$ to $\mathrm{pH}$ 7. Then, they were transferred into $5 \mathrm{~mL}$ glass vials under aseptic conditions and frozen at $-80^{\circ} \mathrm{C}$ for $48 \mathrm{~h}$. The freeze-drying process was carried out at $-50^{\circ} \mathrm{C}$ using a Heto FD4 freeze drier (Heto Lab Equipment, Denmark) and lasted $48 \mathrm{~h}$. In parallel assays, sucrose was added to the neutralized okara (whole and defatted) containing L. plantarum CIDCA 83114 (final concentration of sucrose: $250 \mathrm{mM}$ ). Freeze-drying conditions were the same as those described above. In turn, microorganisms grown in MRS broth were harvested, neutralized and resuspended in $250 \mathrm{mM}$ sucrose or in PBS. Freeze-drying process was carried out as described for bacteria grown in okara. Results were expressed as $\log \mathrm{N} / \mathrm{N}_{0}$, where $\mathrm{N}$ and $\mathrm{N}_{0}$ were the $\mathrm{CFU} / \mathrm{mL}$ after and before freeze-drying, respectively.

\section{Spray-drying}

In a parallel experiment, $100 \mathrm{~mL}$ of okara suspensions (whole and defatted) containing L. plantarum CIDCA 83114 in the stationary phase were neutralized and spray-dried in a laboratory-scale spray-dryer (Büchi B290 mini spray-dryer, Flawil, Switzerland) at a constant air inlet temperature of $180^{\circ} \mathrm{C}$ and an outlet temperature of $65-70^{\circ} \mathrm{C}$. Microorganisms grown in MRS broth 
were harvested neutralized and resuspended in PBS prior spraydrying. Results were expressed as $\log \mathrm{N} / \mathrm{N}_{0}$, where $\mathrm{N}$ and $\mathrm{N}_{0}$ were the $\mathrm{CFU} / \mathrm{mL}$ after and before spray-drying, respectively.

\section{Storage Conditions}

After freeze-drying or spray-drying, samples were stored in silica gel desiccators at $4^{\circ} \mathrm{C}$ for 90 days. During storage, and at regular intervals, freeze-dried and spray-dried samples were rehydrated in PBS, homogenized for $1 \mathrm{~min}$ in a vortex mixer and maintained at room temperature for $30 \mathrm{~min}$. Bacterial suspensions were serially diluted and plate counted on MRS agar, after incubation at $37^{\circ} \mathrm{C}$ for $48 \mathrm{~h}$ in aerobic conditions.

\section{Mathematical Modeling}

Storage plots were fitted using lineal and non-lineal mathematical regressions according to Eqs 1 and 2, respectively:

$$
\log \mathrm{N} / \mathrm{N}_{0}=-\mathrm{kt}
$$

where $\mathrm{N}$ is the CFU/mL at a given time of storage, $\mathrm{N}_{0}$ is the $\mathrm{CFU} / \mathrm{mL}$ at time equal to 0 (immediately after the preservation process), $\mathrm{t}$ is the time of storage (expressed in days) and $\mathrm{k}$ is the constant of bacterial inactivation (expressed in days ${ }^{-1}$ ).

Equation 2 describes non-lineal decays as:

$$
\log \mathrm{N} / \mathrm{N}_{0}=-\mathrm{Ae}^{-\mathrm{k}-\mathrm{t}}+\mathrm{A}
$$

where $\mathrm{N}$ is the $\mathrm{CFU} / \mathrm{mL}$ at a given time of storage, $\mathrm{N}_{0}$ is the $\mathrm{CFU} / \mathrm{mL}$ at time equal to 0 (immediately after the process), $\mathrm{t}$ is the time of storage (expressed in days), $\mathrm{k}$ is the constant of bacterial inactivation (expressed in days ${ }^{-1}$ ) and $A$ is the value of $\log N / N_{0}$ at the plateau.

\section{Water Activity Measurements}

The $\mathrm{a}_{\mathrm{w}}$ of freeze-dried and spray-dried samples was determined using an Aqualab water activity instrument (Aqualab, Model Series 3TE, USA). The equipment was calibrated using standard salt solutions provided by the manufacturer.

\section{Statistical Analysis and Reproducibility}

All experiments were carried out on duplicate samples using three independent cultures of bacteria. The relative differences were reproducible independently on the cultures used. Analysis of variance (ANOVA) of cultivable bacteria corresponding to the different treatments was performed using the statistical program GraphPad Prism version 5.01 for Windows (GraphPad Software, Inc., San Diego, CA, USA 2007). Comparison of means by Tukey methods were tested, and if $p<0.05$ the difference was considered statistically significant.

\section{RESULTS AND DISCUSSION}

The centesimal composition of whole and defatted okara is presented in Table 1, and was comparable to that reported for okara in other works (Vong and Liu, 2016). The FTIR spectra corresponding to whole and defatted okara are shown in Figure 1.

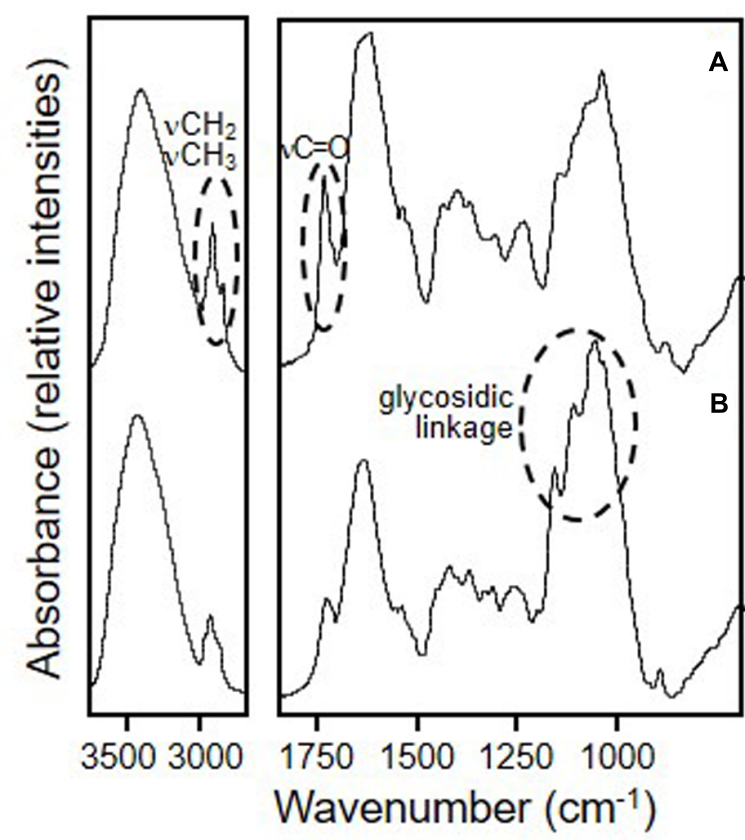

FIGURE 1 | Fourier transform infrared spectroscopy spectra of freeze-dried okara. (A) whole okara; (B) defatted okara. Slashed circles denote the main differences between both spectra.

The main differences observed in the spectra are related with the lipid and carbohydrate bands. In fact, a clear decrease of the typical narrow $v \mathrm{CH}_{2}$ bands corresponding to hydrocarbon lipid chains (2931 and $2860 \mathrm{~cm}^{-1}$ ) and the $v \mathrm{C}=\mathrm{O}$ band at $1750 \mathrm{~cm}^{-1}$ ascribed to the carbonyl groups of fatty acids, was observed in defatted okara. In addition, a noticeable increase of the relative intensity of the bands in the $1200-900 \mathrm{~cm}^{-1}$ region, ascribed to the absorption of the $\mathrm{C}-\mathrm{O}-\mathrm{C}$ glycosidic linkage, was observed (Romano et al., 2014) (Figure 1). This reflects the higher contribution of fiber in defatted okara, which is consistent with the information shown in Table $\mathbf{1 .}$

Figure 2 depicts the growth kinetics of L. plantarum CIDCA 83114 in okara, defatted okara and MRS. No significant differences were observed for microorganisms grown in whole and defatted okara with regard to the control grown in MRS $(p>0.05)$, demonstrating that both whole and defatted okara are

TABLE 1 | Centesimal composition of freeze-dried whole and defatted okara.

\begin{tabular}{lcc}
\hline $\begin{array}{l}\text { Centesimal } \\
\text { composition }\end{array}$ & $\begin{array}{c}\text { Whole okara } \\
\text { (g/100 g d.b.) }\end{array}$ & $\begin{array}{c}\text { Defatted okara } \\
\text { (g/100 g d.b.) }\end{array}$ \\
\hline Protein & $20.90 \pm 1.88$ & $23.25 \pm 2.09$ \\
Lipids & $13.40 \pm 1.24(\mathrm{a})$ & $3.67 \pm 0.34(\mathrm{~b})$ \\
Whole fiber & $54.51 \pm 2.43$ & $60.64 \pm 2.70$ \\
Ash & $1.54 \pm 0.67$ & $1.71 \pm 0.75$ \\
Humidity & $9.64 \pm 2.30$ & $10.73 \pm 2.69$ \\
\hline
\end{tabular}

Different letters $(a, b)$ denote statistically significant differences $(p<0.05)$. 


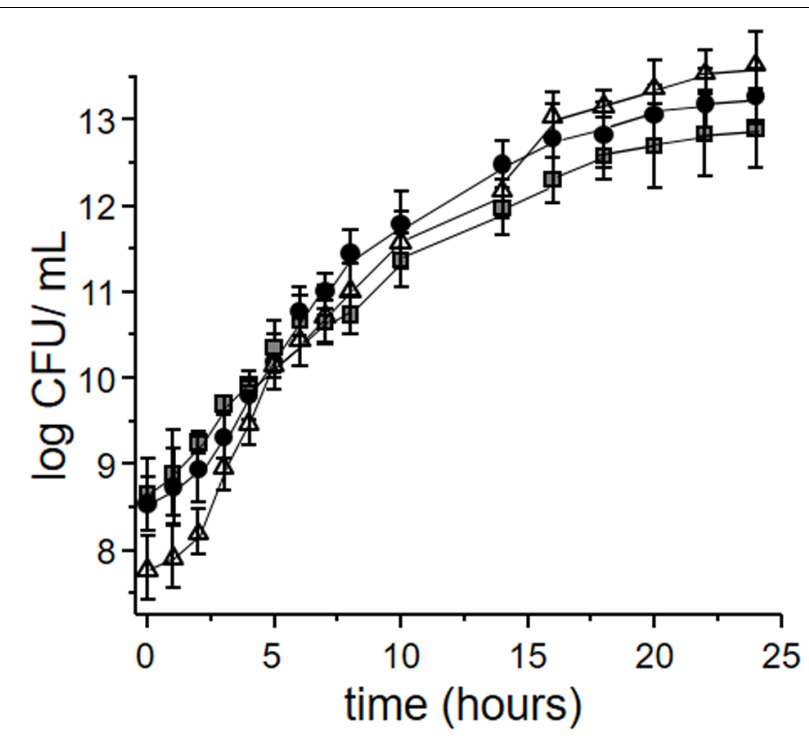

FIGURE 2 | Growth kinetics of Lactobacillus plantarum CIDCA 83114 in whole okara (black circles); defatted okara (gray squares); MRS (control) (white triangles).

as adequate as MRS to grow L. plantarum CIDCA 83114. Because of the large availability of okara, using okara as culture medium represents a clear advantage for the large scale production of starters, as costs can be substantially reduced. It has been reported that certain strains of lactobacilli and bifidobacteria ferment okara, and for this reason, okara has been proposed as a potential source of prebiotic fiber (Espinosa-Martos and Rupérez, 2009).

The composition of culture media strongly determines the composition of bacterial lipid membranes (Smittle et al., 1974; Tymczyszyn et al., 2005), and this latter is in turn related with their stability during preservation processes (Gomez-Zavaglia et al., 2000). For this reason, efforts were made to determine the fatty acid composition of okara lipids, which included C18:2 (54.61\%), C18:1 (21.34\%), C16:0 (11.57\%), and C18:3 (7.97\%) fatty acids, in agreement with the information published by Peñalvo et al. (2004). Taking into account the high contribution of C18:2 and C18:1, okara can be considered as a culture medium enriched in unsaturated fatty acids. Because of the high nutritional value and the technological properties, we have foreseen that okara oil can be used for different applications, thus remaining defatted okara as a final by-product. For this reason, and considering that defatted okara may be a real by-product in case okara oil is used as food ingredient, we decided to include it in this work.

Table 2 shows the fatty acid composition of L. plantarum CIDCA 83114 grown whole and defatted okara and in MRS (control). L. plantarum CIDCA 83114 grown in MRS had mainly C16:0, C18:1 and cycC19:0, with an U/S ratio of 0.63 . Growing microorganisms in okara induced noticeable changes in the fatty acid composition, mainly due to the increase in the polyunsaturated fatty acids (i.e., C18:2) (Table 2). The contribution of other fatty acids, like C16:1 and cycC19:0, strongly dropped for bacteria grown in okara. A moderate
TABLE 2 | Fatty acid composition of Lactobacillus plantarum CIDCA 83114 grown in MRS, whole and defatted okara.

\begin{tabular}{lccc}
\hline Ratio & MRS & Whole okara & Defatted okara \\
\hline & & & \\
C14:0 & $4.68 \pm 0.23(\mathrm{a} 1)^{\mathrm{a}}$ & $2.01 \pm 0.10(\mathrm{a} 1)$ & $1.00 \pm 0.05(\mathrm{a} 1)$ \\
C16:0 & $31.75 \pm 1.59(\mathrm{a} 2)$ & $25.83 \pm 1.29(\mathrm{~b} 2)$ & $21.10 \pm 1.06(\mathrm{~b} 2)$ \\
C16:1 & $6.91 \pm 0.35(\mathrm{a} 3)$ & n.d. & $0.63 \pm 0.03(\mathrm{~b} 3)$ \\
C18:0 & $4.83 \pm 0.24(\mathrm{a} 4)$ & $11.08 \pm 0.56(\mathrm{~b} 4)$ & $6.93 \pm 0.35(\mathrm{a} 4)$ \\
C18:1 & $30.09 \pm 1.52(\mathrm{a} 5)$ & $16.94 \pm 0.85(\mathrm{~b} 5)$ & $20.00 \pm 1.00(\mathrm{~b} 5)$ \\
C18:2 & $0.67 \pm 0.03(\mathrm{a} 6)$ & $44.14 \pm 2.21(\mathrm{~b} 6)$ & $47.32 \pm 2.37(\mathrm{c} 6)$ \\
cycC19:0 & $18.78 \pm 0.94(\mathrm{a} 7)$ & n.d. & $0.49 \pm 0.02(\mathrm{~b} 7)$ \\
U/Sc & 0.63 & 1.57 & 2.30 \\
PUFA/MUFA & & 2.61 & 2.29 \\
\hline
\end{tabular}

aAnalysis of variance has been carried out on rows. They were indicated as: a1, a2, a3, b1, b2, b3, etc. ${ }^{\mathrm{b}}$ n.d, not detected. ${ }^{\mathrm{C} U} / \mathrm{S}$ : unsaturated/saturated ratio. Unsaturated fatty acids include C16:1, C18:1, and C18:2. Saturated fatty acids include C14:0, C16:0, C18:0, and cycC19:0. dPUFAMUFA: polyunsaturated/monounsaturated ratio. Polyunsaturated fatty acids include C18:2 and monounsaturated fatty acids include C16:1 and C18:1.

decrease of C16:0 and C18:1 was also observed. As result of these changes, an inversion in the U/S ratio was observed for microorganisms grown in whole and defatted okara. Moreover, due to the high contribution of C18:2, the PUFA/MUFA ratio also increased with regard to the controls grown in MRS (Table 2). It has been reported that growing bacteria in media enriched with unsaturated fatty acids induces an increase in the U/S fatty acids ratio, which prevents lipids from being closely packed, and thus increases membrane fluidity (Muller et al., 2011; Hansen et al., 2015). Hansen et al. (2015) reported that the addition of $10 \mathrm{mg} / \mathrm{L}$ C18:2 to the growth medium promotes its incorporation into bacterial membranes. If considered that: (i) defatted okara had a lipid concentration of $3.67 \pm 0.34 \mathrm{~g} / 100 \mathrm{~g}$ d.b. (Table 1), (ii) bacteria were grown in $5 \% \mathrm{w} / \mathrm{v}$ okara suspensions (see Materials and Methods) and (iii) okara fatty acids included 54.61\% C18:2, it can be calculated that microorganisms grown in defatted okara were cultured in the presence of $1 \mathrm{mg} / \mathrm{mL}$ C18:2. This concentration was higher than that reported by Hansen et al. (2015), thus explaining the increase of PUFA/MUFA ratio in microorganisms grown in defatted okara (Table 2). The same rationalization can be carried out for microorganisms grown in whole okara, which explains the changes observed in the fatty acid composition (Table 2 ).

The effect of the growth and dehydration conditions on bacterial recovery was further analyzed. Freeze-dried microorganisms (with and without sucrose) had lower $\mathrm{a}_{\mathrm{w}}$ than spray-dried ones, and bacteria grown in okara (whole and defatted), lower values than bacteria grown in MRS (Table 3). Bacteria grown in whole okara were those showing the lowest loss of viability after freeze-drying (left groups of bars in Figure 3). The $\log \mathrm{N} / \mathrm{N}_{0}$ value for freeze-dried bacteria grown in defatted okara was significantly lower $(p<0.05)$, and comparable with that of bacteria grown in MRS and suspended in PBS $(p>0.05)$. The addition of sucrose in the dehydration media improved the recovery of microorganisms grown in defatted okara and MRS after freeze-drying $(p<0.05)$ and did not have a significant effect on bacteria grown in whole okara $(p>0.05)$ (middle group 
TABLE 3 | Water activity and inactivation constants of $L$. plantarum CIDCA 83114 grown in okara (whole and defatted) and MRS, and then freeze-dried (with and without $250 \mathrm{mM}$ sucrose) or spray-dried.

\begin{tabular}{|c|c|c|c|c|c|}
\hline \multirow[t]{2}{*}{ Growth medium } & \multirow[t]{2}{*}{ Dehydration condition } & \multirow[t]{2}{*}{$a_{w}{ }^{a}$} & \multicolumn{3}{|c|}{ Fitting } \\
\hline & & & No significant decay & Linear ${ }^{b}$ & Non-linearc \\
\hline \multirow[t]{3}{*}{ Whole okara } & Freeze-drying & 0.2544 & & k: 0.053 days $^{-1}\left(R^{2}: 0.9618\right)$ & \\
\hline & Freeze-drying with sucrose & 0.2466 & $\mathrm{X}^{d}$ & & \\
\hline & Spray-drying & 0.3754 & $x$ & & \\
\hline \multirow[t]{3}{*}{ Defatted okara } & Freeze-drying & 0.2635 & & & k: 0.04254 days $^{-1} \mathrm{~A}: 2.994\left(R^{2}: 0.9239\right)$ \\
\hline & Freeze-drying with sucrose & 0.2525 & $x$ & & \\
\hline & Spray-drying & 0.3904 & & & k: 0.03561 days $^{-1} \mathrm{~A}: 2.881\left(R^{2}: 0.9536\right)$ \\
\hline \multirow[t]{3}{*}{ MRS } & Freeze-drying & 0.4141 & & k: 0.0780 days $^{-1}\left(R^{2}: 0.9419\right)$ & \\
\hline & Freeze-drying with sucrose & 0.2884 & & k: 0.035 days $^{-1}\left(R^{2}: 0.9622\right)$ & \\
\hline & Spray-drying & 0.4772 & & & $\mathrm{k}: 0.1216$ days $^{-1} \mathrm{~A}: 4.082\left(R^{2}: 0.9193\right)$ \\
\hline
\end{tabular}

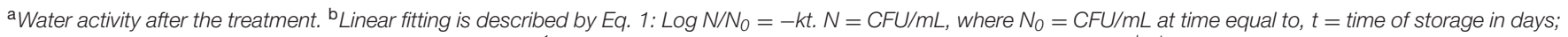

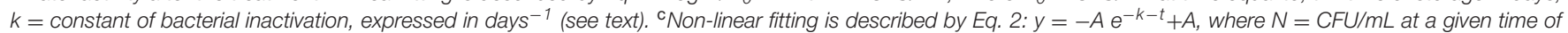

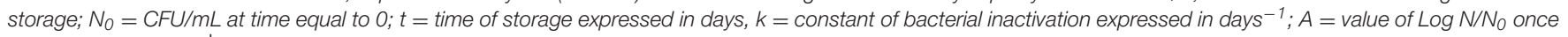
attained the plateau. ${ }^{\mathrm{d} X} \mathrm{X}$ denote no significant decay during storage.

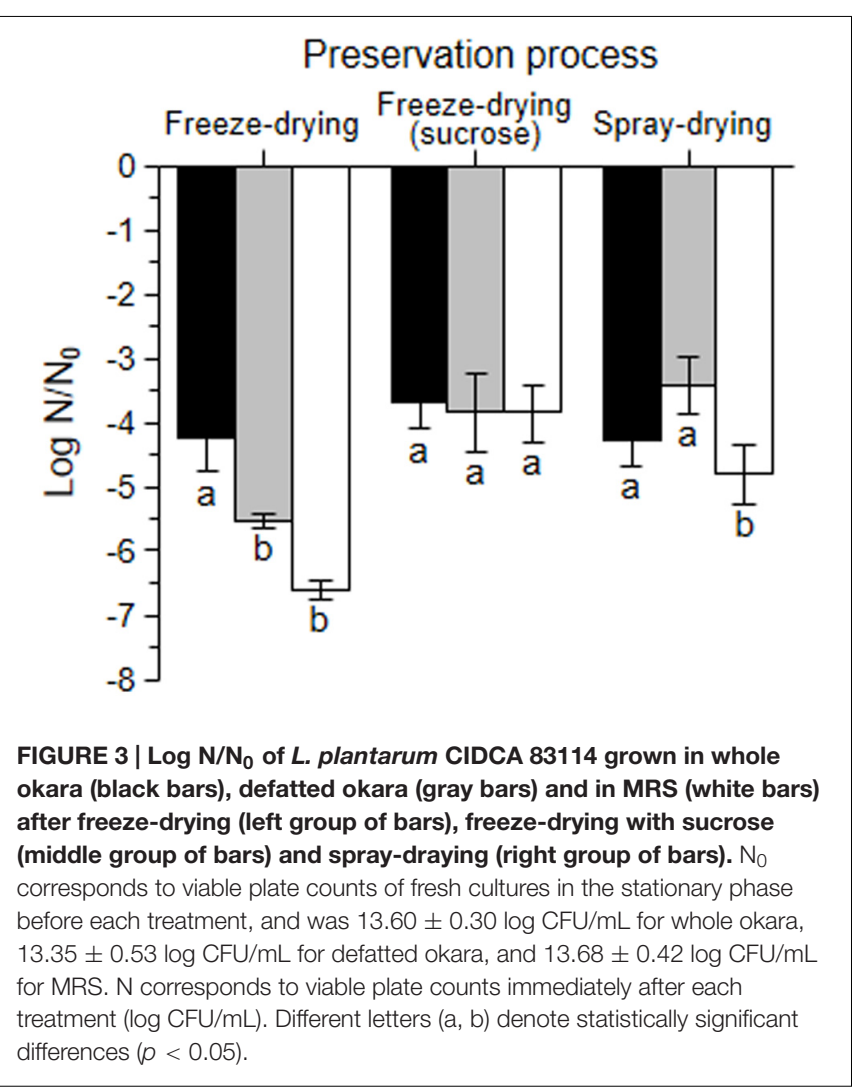

of bars). It is interesting to note that the growth medium did not induce significant differences after freeze-drying with sucrose $(p>0.05)$ (middle group of bars). For the spray-drying process, the loss of viability for microorganisms grown in whole and defatted okara was significantly lower than that of bacteria grown in MRS and suspended in PBS ( $p<0.05$ ) (right group of bars).

The effect of the growth medium on the preservation processes was also analyzed. Microorganisms grown in whole okara showed no significant differences in the $\log \mathrm{N} / \mathrm{N}_{0}$ after the three treatments $(p>0.05)$ (Figure 3). In turn, for bacteria grown in defatted okara and in MRS, spray-drying and freeze-drying with sucrose were significantly less harmful processes than freezedrying without sucrose $(p<0.05)$.

The viability loss of L. plantarum CIDCA 83114 during storage at $4^{\circ} \mathrm{C}$ is shown in Figure 4. Freeze-drying was the most harmful process for L. plantarum CIDCA 83114 grown in the three culture media (Figure 4A). After 90 days of storage at $4^{\circ} \mathrm{C}$, the viability of microorganisms grown in whole and defatted okara decayed $4.62 \pm 0.25$ and $2.65 \pm 0.06$ logarithmic units, respectively with regard to the corresponding viability obtained immediately after freeze-drying, considered as $\mathrm{N}_{0}$ (time equal to 0 ). A significantly more deleterious effect was observed for microorganisms grown in MRS $(<0.05)$, as a decrease of $7.10 \pm 0.14$ logarithmic units was observed after 90 days of storage at $4^{\circ} \mathrm{C}$. The addition of sucrose to the dehydration media had a protective effect during storage in all the three conditions assayed (Figure 4B). In this condition, microorganisms grown in whole and defatted okara did not show a significant decrease of viability with regard of the corresponding values obtained immediately after freeze-drying $(p>0.05)$ (Figure 4B). Although viability of microorganisms grown in MRS significantly decreased during storage $(p<0.05)$, this decrease was lower than that observed for bacteria grown in MRS and freeze-dried without sucrose (Figure 4A). In turn, spray-drying resulted an adequate process to stabilize bacteria grown in whole and defatted okara for 90 days at $4^{\circ} \mathrm{C}$ (Figure 4C). In this condition, no significant viability loss was observed for bacteria grown in whole okara $(p<0.05)$, and a loss of $2.71 \pm 0.22$ logarithmic units, for bacteria grown in defatted okara. Growing bacteria in MRS before spray-drying induced the highest drop of viability ( $4.15 \pm 0.66$ logarithmic units after 90 days of storage).

Polyhydroxy compounds, namely sugars and fiber, are generally used as protective compounds during freeze-drying, spray-drying and storage of lactic acid bacteria (Tymczyszyn et al., 2008; Santos et al., 2014; Romano et al., 2015). Fiber and oligosaccharides present in okara could improve the bacterial 


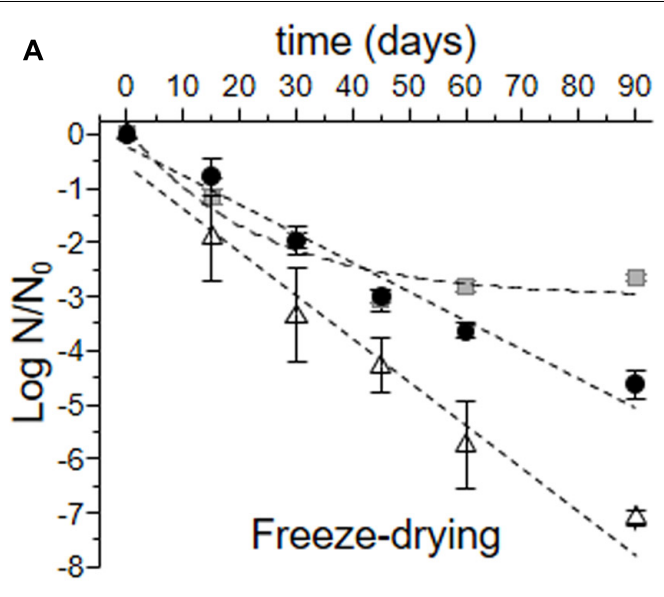

B

time (days)

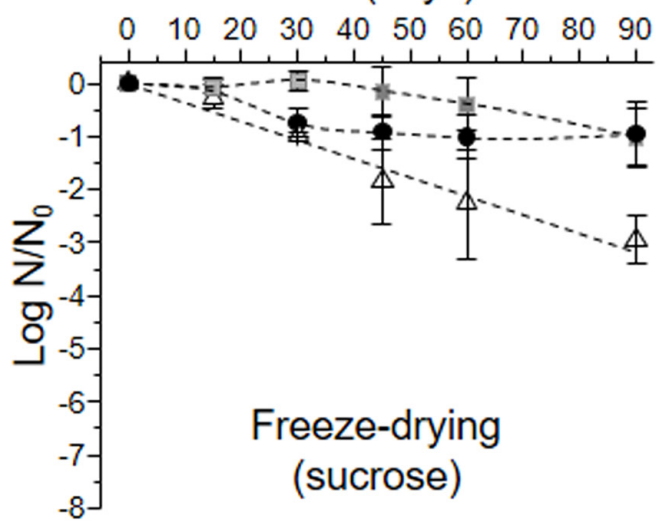

C

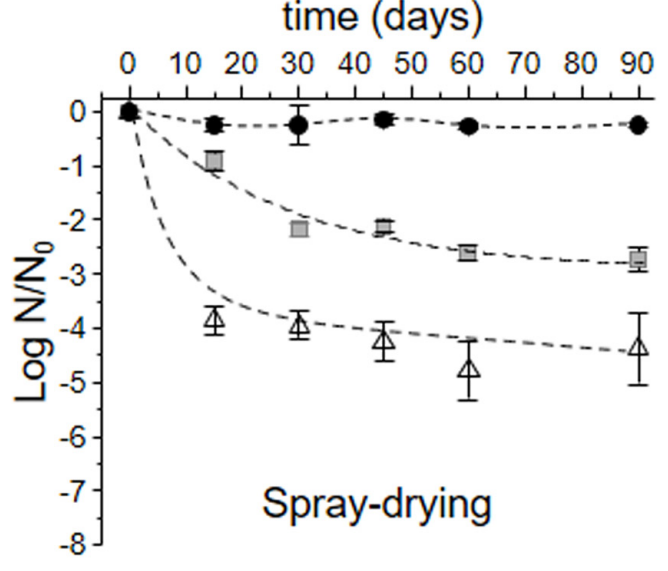

FIGURE 4 | Log N/ $\mathrm{N}_{0}$ of L. plantarum CIDCA 83114 during storage. $\mathrm{N}_{0}$ : viability obtained immediately after each preservation process (in log $\mathrm{CFU} / \mathrm{mL}$ ) and correspond to the values of $\mathrm{N}$ used in Figure 3. N: viability after each time of storage (log $\mathrm{CFU} / \mathrm{mL}$ ). Full black circles: bacteria grown in whole okara; gray squares: bacteria grown in defatted okara; white triangles: bacteria grown in MRS. (A) Freeze-drying; (B) Freeze-drying in the presence of sucrose; (C) Spray-drying. Dash lines show the mathematical regressions. In the cases of no significant decays (see Table 3), experimental values were just connected. capacity to overcome freeze-drying and spray-drying processes and also stabilize microorganisms during storage (Figures 3, 4) (Hincha et al., 2003; Sosa et al., 2016). The addition of sucrose in the dehydration medium improved the recovery of microorganisms grown in defatted okara and in MRS (Figure 3), which was an expected result considering the reported protective effect of sucrose during preservation of lactic acid bacteria (Tymczyszyn et al., 2007a,b). In this regard, it is worth to mention that although there are recent articles reporting the sucrose metabolism in L. plantarum strains (Chen et al., 2014; MendozaLlerenas et al., 2016), in this work, L. plantarum CIDCA 83114 is exposed to sucrose in non-growing conditions. Thus, sucrose is not hydrolyzed and acts as a protective agent.

The mathematical fitting of the storage graphs allowed the description of three different groups:

(a) no significant viability decays after 90 days of storage: this group included bacteria grown in whole okara and freeze-dried with sucrose or spray-dried, and microorganisms grown in defatted okara and freeze-dried with sucrose (Figure 4 and Table 3).

(b) linear decay after 90 days of storage: this group included bacteria grown in okara and freeze-dried without sucrose, and those grown in MRS, freeze-dried with or without sucrose (Table 3). Eq. 1 describes the behavior of this group.

(c) non-linear decay after 90 days of storage: this group is composed of bacteria grown in defatted okara freeze-dried without sucrose or spray-dried, and bacteria grown in MRS and then, spray-dried (Table 3). Eq. 2 describes the behavior of this group.

For probiotic products, the European Food Safety Agency (EFSA) requires a bacterial viability of at least $10^{6}-10^{7} \mathrm{CFU} / \mathrm{g}$ at the moment of being consumed (Hill et al., 2014). The $k$ parameters obtained from Eqs 1 and 2 (Table 3) represent important tools to determine these values and in consequence, the shelf-life of L. plantarum CIDCA 83114 stabilized in okara matrices at the storage conditions.

\section{CONCLUSION}

Fermenting okara with $L$. plantarum CIDCA 83114 appears as an interesting strategy to deal with okara spoilage and disposal. In addition, dehydrating microorganisms in okara resulted in an adequate approach to stabilize L. plantarum CIDCA 83114. In particular, the successful stabilization of fermented okara by spray-drying appears as a cost-effective solution for the production of starters at an industrial level with a lowenergy consumption. The composition of okara had a strong influence on bacterial recovery after freeze-drying, spray-drying and storage: the presence of PUFAs induced an increase in the U/S and PUFA/MUFA ratios of lipid membranes, increasing membrane fluidity, and the fiber and oligosaccharides present in okara acted as protectants during dehydration and storage.

Using a by-product produced in large quantities as culture medium provides a cost-effective alternative for the production of starters at large scale. In addition, it provides a valuable solution 
for industrials, as they can solve two problems: okara disposal and availability of low-cost culture media. Regarding a nutritional perspective, okara provides high quality nutrients as vehicles of potentially probiotic microorganisms, whose importance in human and animal health is out of question. Taking this into account, the results support the use of okara matrices as suitable vehicles for probiotic strains, with promising applications in the development of novel functional foods and feeds.

\section{AUTHOR CONTRIBUTIONS}

GQ and EG did the experimental work. EG and AG-Z conceived the work, analyzed and discussed results and wrote the manuscript.

\section{REFERENCES}

Al-Madboly, L. A., and Abdullah, A. K. (2015). Potent antagonistic activity of Egyptian Lactobacillus plantarum against multiresistant and virulent foodassociated pathogens. Front. Microbiol. 6:347. doi: 10.3389/fmicb.2015.00347

Association of Official Analytical Chemists [AOAC] (1980). Official Methods of Analysis of Association of Official Analytical Chemists, 13th Edn. Washington, DC: Association of Official Analytical Chemists.

Association of Official Analytical Chemists [AOAC] (1995). Official Methods of Analysis Association of Official Analytical Chemists, 2 Vol. 16th Edn. Washington, DC: Association of Official Analytical Chemists.

Bedani, R., Campos, M. M., Castro, I. A., Rossi, E. A., and Saad, S. M. I. (2014). Incorporation of soybean by-product okara and inulin in a probiotic soy yoghurt: texture profile and sensory acceptance. J. Sci. Food Agric. 94, 119-125. doi: $10.1002 /$ jsfa.6212

Bedani, R., Rossi, E. A., Cavallini, D. C. U., Pinto, R. A., Vendramini, R. C., Augusto, E. M., et al. (2015). Influence of daily consumption of synbiotic soybased product supplemented with okara soybean by-product on risk factors for cardiovascular diseases. Food Res. Int. 73, 142-148. doi: 10.1016/j.foodres.2014. 11.006

Bedani, R., Rossi, E. A., and Isay Saad, S. M. (2013). Impact of inulin and okara on Lactobacillus acidophilus La-5 and Bifidobacterium animalis Bb-12 viability in a fermented soy product and probiotic survival under in vitro simulated gastrointestinal conditions. Food Microbiol. 34, 382-389. doi: 10.1016/j.fm. 2013.01.012

Berbegal, C., Peña, N., Russo, P., Grieco, F., Pardo, I., Ferrer, S., et al. (2016). Technological properties of Lactobacillus plantarum strains isolated from grape must fermentation. Food Microbiol. 57, 187-194. doi: 10.1016/j.fm.2016. 03.002

Capozzi, V., Menga, V., Digessù, A. M., De Vita, P., van Sinderen, D., Cattivelli, L., et al. (2011). Biotechnological production of vitamin B2-enriched bread and pasta. J. Agric. Food Chem. 59, 8013-8020. doi: 10.1021/jf201519h

Capozzi, V., Russo, P., Ladero, V., Fernández, M., Fiocco, D., Alvarez, M. A., et al. (2012). Biogenic amines degradation by Lactobacillus plantarum: toward a potential application in wine. Front. Microbiol. 3:122. doi: 10.3389/fmicb.2012. 00122

Carvalho, A., Silva, J., Hob, P., Teixeira, P., Malcata, F. X., and Gibbs, P. (2004). Relevant factors for the preparation of freeze-dried lactic acid bacteria. Int. Dairy J. 14, 835-847. doi: 10.1016/j.idairyj.2004.02.001

Chen, C., Zhoua, F., Rena, J., Aia, L., Donga, Y., Wua, Z., et al. (2014). Cloning, expression and functional validation of a $\beta$-fructofuranosidase from Lactobacillus plantarum. Proc. Biochem. 49, 758-767. doi: 10.1016/j.procbio. 2014.02.013

de Man, J. O., Rogosa, M., and Sharpe, M. E. (1960). A medium for the cultivation of lactobacilli. J. Appl. Bacteriol. 23, 130-135. doi: 10.1111/j.1365-2672.1960. tb00188.x

Espinosa-Martos, I., and Rupérez, P. (2009). Indigestible fraction of okara from soybean: composition, physicochemical properties and in vitro fermentability

\section{FUNDING}

This work was supported by the Argentinean Agency for the Scientific and Technological Promotion (ANPCyT) (Projects PICT/2014/0912 and PICT/2013/1258) and the Argentinean National Research Council (CONICET) (PIP2012-2014114201101-00024).

\section{ACKNOWLEDGMENTS}

EG and AG-Z are members of the research career CONICET. GQ is doctoral fellow from CONICET. Dr. G. Kociubinski is especially acknowledged for his helpful suggestions and discussions.

by pure cultures of Lactobacillus acidophilus and Bifidobacterium bifidum. Eur. Food Res. Technol. 228, 685-693. doi: 10.1007/s00217-008-0979-7

Fonseca, F., Cenard, S., and Passot, S. (2015). "Freeze-drying of lactic acid bacteria," in Cryopreservation and Freeze-drying Protocols, eds W. F. Wolkers and H. Oldenhof (New York, NY: Springer Science+Business Media). doi: 10.1007/ 978-1-4939-2193-5_24

Garrote, G. L., Abraham, A. G., and De Antoni, G. L. (2001). Chemical and microbiological characterisation of kefir grains. J. Dairy Res. 68, 639-652.

Golowczyc, M. A., Gerez, C. L., Silva, J., Abraham, A. G., De Antoni, G. L., and Teixeira, P. (2011a). Survival of spray-dried Lactobacillus kefir is affected by different protectants and storage conditions. Biotechnol. Lett. 33, 681-686. doi: 10.1007/s10529-010-0491-6

Golowczyc, M. A., Silva, J., Abraham, A. G., De Antoni, G. L., and Teixeira, P. (2010). Preservation of probiotic strains isolated from kefir by spray drying. Lett. Appl. Microbiol. 50, 7-12. doi: 10.1111/j.1472-765X.2009.02759.x

Golowczyc, M. A., Silva, J., Teixeira, P., De Antoni, G. L., and Abraham, A. G. (2011b). Cellular injuries of spray-dried Lactobacillus spp. isolated from kefir and their impact on probiotic properties. Int. J. Food Microbiol. 144, 556-560. doi: 10.1016/j.ijfoodmicro.2010.11.005

Golowczyc, M. A., Vera, C., Santos, M., Guerrero, C., Carasi, P., Illanes, A., et al. (2013). Use of whey permeate containing in situ synthesised galactooligosaccharides for the growth and preservation of Lactobacillus plantarum. J. Dairy Res. 80, 374-381. doi: 10.1017/S0022029913000356

Gomez-Zavaglia, A., Disalvo, E. A., and De Antoni, G. L. (2000). Fatty acid composition and freeze-thaw resistance in lactobacilli. J. Dairy Res. 67, 241-247. doi: 10.1017/S0022029900004179

Hansen, M. L. R. W., Petersen, M. A., Risbo, J., Hümmer, M., and Clausen, A. (2015). Implications of modifying membrane fatty acid composition on membrane oxidation, integrity, and storage viability of freeze-dried probiotic, Lactobacillus acidophilus La-5. Biotechnol. Prog. 31, 799-807. doi: 10.1002/btpr. 2074

Hill, C., Guarner, F., Reid, G., Gibson, G. R., Merenstein, D. J., Pot, B., et al. (2014). Expert consensus document: The International Scientific Association for Probiotics and Prebiotics consensus statement on the scope and appropriate use of the term probiotic. Nat. Rev. Gastroenterol. 11, 506-514. doi: 10.1038/ nrgastro.2014.66

Hincha, D. K., Zuther, E., and Heyer, A. G. (2003). The preservation of liposomes by raffinose family oligosaccharides during drying is mediated by effects on fusion and lipid phase transitions. Biochim. Biophys. Acta 1612, 172-177. doi: 10.1016/S0005-2736(03)00116-0

Holt, C. (1982). Inorganic constituents of milk III. The colloidal calcium phosphate of cow's milk. J. Dairy Res. 49, 29-38. doi: 10.1017/S002202990002210X

Jimenez-Escrig, A., Tenorio, M. D., Espinosa-Martos, I., and Ruperez, P. (2008). Health-promoting effects of a dietary fiber concentrate from the soybean byproduct okara in rats. J. Agric. Food Chem. 56, 7495-7501. doi: 10.1021/ jf800792y

Kakisu, E., Abraham, A. G., Tironi Farinati, C., Ibarra, C., and De Antoni, G. L. (2013). Lactobacillus plantarum isolated from kefir protects vero cells from 
cytotoxicity by type-II Shiga toxin from Escherichia coli O157:H7. J. Dairy Res. 80, 64-71. doi: 10.1017/S0022029912000659

Kitawaki, R., Takagi, N., Iwasaki, M., Asao, H., Okada, S., and Fukuda, M. (2007). Plasma cholesterol-lowering effects of soymilk and okara treated by lactic acid fermentation in rats. J. Jpn. Soc. Food Sci. 54, 379-382. doi: 10.3136/nskkk. 54.379

Kleerebezem, M., Boekhorst, J., van Kranenburg, R., Molenaar, W., Kuipers, O. P., Leer, R., et al. (2003). Complete genome sequence of Lactobacillus plantarum WCFS1. Proc. Natl. Acad. Sci. U.S.A. 100, 1990-1995. doi: 10.1073/pnas. 0337704100

Lê, N. T., Champagne, C. P., Lee, B. H., and Goulet, J. (2004). Growth of Lactobacillus paracasei ssp. paracasei on tofu whey. Int. J. Food Microbiol. 89, 67-75. doi: 10.1016/S0168-1605(03)00109-0

Li, B., Qiao, M., and Lu, F. (2012). Composition, nutrition, and utilization of okara (soybean residue). Food Rev. Int. 28, 231-252. doi: 10.1080/87559129. 2011.595023

Li, Y., Hao, J., Cheng, Y., Zhao, R., Yin, L., and Li, L. (2012). Improvement of okara mouthfeel by Aspergillus niger and Aspergillus oryzae fermentation. Trans. Chin. Soc. Agric. Eng. 28, 248-253. doi: 10.3969/j.issn.1002-6819.2012. 07.041

Marinetti, G. V. (1993). "Isolation, analysis and identification of lipids," in Techniques of Lipidology, eds M. Kates, H. R. Burdon, and P. H. Knippemberg (Amsterdam: Elsevier), 220-227. doi: 10.1016/S0075-7535(08) 70544-8

McCleary, B. V. (2007). An integrated procedure for the measurement of total dietary fibre (including resistant starch), non-digestible oligosaccharides and available carbohydrates. Anal. Bioanal. Chem. 389, 291-308. doi: 10.1007/ s00216-007-1389-6

Mendoza-Llerenas, E. O., Pérez, D. J., Gómez-Sandoval, Z., Escalante-Minakata, P., Ibarra-Junquera, V., Razo-Hernández, R. S., et al. (2016). Lactobacillus plantarum WCFS1 $\beta$-fructosidase: evidence for an open funnel-like channel through the catalytic domain with importance for the substrate selectivity. Appl. Biochem. Biotechnol. 180, 1056-1075. doi: 10.1007/s12010-0162152-2

Muller, J. A., Ross, R. P., Sybesma, W. F. H., Fitzgerald, G. F., and Stanton, C. (2011). Modification of the technical properties of Lactobacillus johnsonii NCC 533 by supplementing the growth medium with unsaturated fatty acids. Appl. Environ. Microbiol. 77, 6889-6898. doi: 10.1128/AEM.05213-11

O’Toole, D. K. (1999). Characteristics and use of okara, the soybean residue from soy milk production: a review. J. Agric. Food Chem. 47, 363-371. doi: 10.1021/ jf9807541

Peñalvo, J. L., Castilho, M. C., Silveira, M. I. N., Matallana, M. C., and Torija, M. E. (2004). Fatty acid profile of traditional soymilk. Eur. Food Res. Technol. 219, 251-253. doi: 10.1007/s00217-004-0945-y

Romano, N., Tavera-Quiroz, M. J., Bertola, N., Mobili, P., Pinotti, A., and GómezZavaglia, A. (2014). Edible methylcellulose-based films containing fructooligosaccharides as vehicles for lactic acid bacteria. Food Res. Int. 64, 560-566. doi: 10.1016/j.foodres.2014.07.018

Romano, N., Tymczyszyn, E., Mobili, A., and Gómez-Zavaglia, A. (2015). "Chapter 10: Prebiotics as protectants of lactic acid bacteria," in Probiotics, Prebiotics, and Synbiotics: Bioactive Foods in Health Promotion, Part 1: Prebiotics in Health Promotion, 2nd Edn, eds R. R. Watson and V. R. Preedy (Cambridge, MA: Academic Press), 155-164. doi: 10.1016/B978-0-12-8021897.00010-1

Santos, M., Gerbino, E., Araujo-Andrade, C., Tymczyszyn, E. E., and GomezZavaglia, A. (2014). Stability of freeze-dried Lactobacillus delbrueckii subsp. bulgaricus in the presence of galacto-oligosaccharides and lactulose as determined by near infrared spectroscopy. Food Res. Int. 59, 53-60. doi: 10. 1016/j.foodres.2014.01.054
Smittle, R. B., Gilliland, S. E., Speck, M. L., and Walter, W. M. Jr. (1974). Relationship of cellular fatty acid composition to survival of Lactobacillus bulgaricus in liquid nitrogen. Appl. Microbiol. 27, 738-743.

Song, D., Chang, S. K. C., and Ibrahim, A. A. (2009). Effect of fermentation substrates on enzyme production and degradation of oligosaccharides in pinto bean flour as affected by particle size. J. Food Process. Pres. 33, 527-546. doi: $10.1111 / j .1745-4549.2008 .00304 . x$

Sosa, N., Gerbino, E., Golowczyc, M. A., Schebor, C., Gómez-Zavaglia, A., and Tymczyszyn, E. E. (2016). Effect of galacto-oligosaccharides: maltodextrin matrices on the recovery of Lactobacillus plantarum after spray-drying. Front. Microbiol. 7:584. doi: 10.3389/fmicb.2016.00584

Stanojevic, S. P., Barac, M. B., Pesic, M. B., Jankovic, V. S., and Vucelic-Radovic, B. V. (2013). Bioactive proteins and energy value of okara as a byproduct in hydrothermal processing of soy milk. J. Agric. Food Chem. 61, 9210-9219. doi: $10.1021 /$ jf 4012196

Tavera-Quiroz, M. J., Romano, N., Mobili, P., Pinotti, A., Gomez-Zavaglia, A., and Bertola, N. (2015). Green apple baked snacks functionalized with edible coatings of methylcellulose containing Lactobacillus plantarum. J. Funct. Foods 16, 164-173. doi: 10.1016/j.jff.2015.04.024

Tymczyszyn, E. E., Díaz, M. R., Gómez-Zavaglia, A., and Disalvo, E. A. (2007a). Volume recovery, surface properties and membrane integrity of Lactobacillus delbrueckii subsp. bulgaricus dehydrated in the presence of trehalose or sucrose. J. Appl. Microbiol. 103, 2410-2419. doi: 10.1111/j.1365-2672.2007.03482.x

Tymczyszyn, E. E., Díaz, R., Pataro, A., Sandonato, N., Gómez-Zavaglia, A., and Disalvo, E. A. (2008). Critical water activity for the preservation of Lactobacillus bulgaricus by vacuum drying. Int. J. Food Microbiol. 128, 342-347. doi: 10.1016/ j.ijfoodmicro.2008.09.009

Tymczyszyn, E. E., Gomez-Zavaglia, A., and Disalvo, E. A. (2005). Influence of the growth at high osmolality on the lipid composition, water permeability and osmotic response of Lactobacillus bulgaricus. Arch. Biochem. Biophys. 443, 66-73. doi: 10.1016/j.abb.2005.09.004

Tymczyszyn, E. E., Gómez-Zavaglia, A., and Disalvo, E. A. (2007b). Effect of sugars and growth media on the dehydration of Lactobacillus delbrueckii ssp. bulgaricus. J. Appl. Microbiol. 102, 845-851. doi: 10.1111/j.1365-2672.2006. 03108.x

Villanueva-Suárez, M. J., Pérez-Cózar, M. L., and Redondo-Cuenca, A. (2013). Sequential extraction of polysaccharides from enzymatically hydrolyzed okara byproduct: physicochemical properties and in vitro fermentability. Food Chem. 141, 1114-1119. doi: 10.1016/j.foodchem.2013.03.066

Vong, W. C., and Liu, S. Q. (2016). Biovalorisation of okara (soybean residue) for food and nutrition. Trends Food Sci. Technol. 52, 139-147. doi: 10.1016/j.tifs. 2016.04.011

Yadav, R., Puniya, A. K., and Shukla, P. (2016). Probiotic properties of Lactobacillus plantarum RYPR1 from an indigenous fermented beverage Raabadi. Front. Microbiol. 7:1683. doi: 10.3389/fmicb.2016.01683

Zhu, Y., Li, X., Liu, R., and Li, H. (2014). Antioxidant activity and nutritional characterization of okara fermented by various microorganisms. J. Chin. Inst. Food Sci. Tech. 14, 20-27. doi: 10.1080/87559129.2011.595023

Conflict of Interest Statement: The authors declare that the research was conducted in the absence of any commercial or financial relationships that could be construed as a potential conflict of interest.

Copyright ( 2017 Quintana, Gerbino and Gómez-Zavaglia. This is an open-access article distributed under the terms of the Creative Commons Attribution License (CC BY). The use, distribution or reproduction in other forums is permitted, provided the original author(s) or licensor are credited and that the original publication in this journal is cited, in accordance with accepted academic practice. No use, distribution or reproduction is permitted which does not comply with these terms. 